\title{
Cadmium reduces nitric oxide production by impairing phosphorylation of endothelial nitric oxide synthase
}

\author{
Syamantak Majumder, Ajit Muley, Gopi Krishna Kolluru, Samir Saurabh, \\ K.P. Tamilarasan, Sidhharth Chandrasekhar, Hima Bindu Reddy, Sharad Purohit, \\ and Suvro Chatterjee
}

\begin{abstract}
Cadmium (Cd) perturbs vascular health and interferes with endothelial function. However, the effects of exposing endothelial cells to low doses of $\mathrm{Cd}$ on the production of nitric oxide (NO) are largely unknown. The objective of the present study was to evaluate these effects by using low levels of $\mathrm{CdCl}_{2}$ concentrations, ranging from 10 to $1000 \mathrm{nmol} / \mathrm{L}$. $\mathrm{Cd}$ perturbations in endothelial function were studied by employing wound-healing and MTT (3-(4,5-dimethylthiazol-2yl)-2,5-diphenyltetrazolium bromide) assays. The results suggest that a $\mathrm{CdCl}_{2}$ concentration of $100 \mathrm{nmol} / \mathrm{L}$ maximally attenuated NO production, cellular migration, and energy metabolism in endothelial cells. An egg yolk angiogenesis model was employed to study the effect of $\mathrm{Cd}$ exposure on angiogenesis. The results demonstrate that NO supplementation restored Cd-attenuated angiogenesis. Immunofluorescence, Western blot, and immuno-detection studies showed that low levels of $\mathrm{Cd}$ inhibit NO production in endothelial cells by blocking eNOS phosphorylation, which is possibly linked to processes involving endothelial function and dysfunction, including angiogenesis.
\end{abstract}

Key words: cadmium, endothelial cells, angiogenesis, nitric oxide.

Résumé : Le cadmium (Cd) perturbe la santé vasculaire et interfère avec la fonction endothéliale. Cependant, le modus operandi des effets d'une exposition de l'endothélium à de faibles doses de Cd en relation avec l'oxyde nitrique est essentiellement inconnu. L'objectif de cette étude était d'évaluer les effets d'une exposition des cellules endothéliales à de faibles doses de Cd sur la production d'oxyde nitrique. Les concentrations de Cd allant de 10 à $1000 \mathrm{nmol} / \mathrm{L}$ ont été utilisées pour investiguer les effets du Cd sur la production d'oxyde nitrique. La perturbation des fonctions endothéliales par le Cd ont été étudiées à l'aide d'essais de cicatrisation et d'un essai MTT (bromure de 3-(4,5-dimethylthiazol-2-yl)-2,5-diphényltétrazolium). Les résultats suggèrent qu'une concentration de $100 \mathrm{nmol} / \mathrm{L}$ de $\mathrm{Cd}$ atténue la production d'oxyde nitrique, la migration cellulaire et le métabolisme énergétique des cellules endothéliales. Un modèle d'angiogenèse vitelline a été utilisé pour étudier l'effet d'une exposition au Cd sur l'angiogenèse. Les résultats démontrent que, alors que de faibles concentrations de Cd atténuent l'angiogenèse, une supplémentation en oxyde nitrique la rétablit. Des études en immunofluorescence, en buvardage Western et en immuno-détection ont montré que le Cd empêche la phosphorylation de l'eNOS pour bloquer la production d'oxyde nitrique dans les cellules endothéliales. En conclusion, les résultats de notre étude indiquent que de faibles concentrations de Cd bloquent la production d'oxyde nitrique en bloquant la phosphorylation de l'eNOS, ce qui est possiblement lié à des processus impliquant la fonction et la dysfonction endothéliales, y compris l'angiogenèse.

Mots-clés : cadmium, cellules endothéliales, angiogenèse, oxyde nitrique.

[Traduit par la Rédaction]

\section{Introduction}

Cadmium $(\mathrm{Cd})$ is a naturally available metallic component in the earth's crust and is implicated in the lives of plants, animals, and humans (Bokori and Fekete 1995).
Although it has many uses in consumer products, such as batteries, metal coatings, and some metal alloys, it has also been declared a human carcinogen (Waalkes 2003). One of the most serious causes of $\mathrm{Cd}$ poisoning is tobacco smoking

Received 5 June 2007. Revision received 10 October 2007. Accepted 18 October 2007. Published on the NRC Research Press Web site at bcb.nrc.ca on 25 January 2008.

Abbreviations: Cd, cadmium; DEAN, diethylamine NONOate; DMEM, Dulbecco's modified Eagle's medium; ECs, endothelial cells; eNOS, endothelial nitric oxide synthase; FBS, fetal bovine serum; 5-FU, 5-fluorouracil; MTT, 3-(4,5-dimethylthiazol-2-yl)-2,5diphenyltetrazolium bromide;NO, nitric oxide; NOS, nitric oxide synthase; PBS, phosphate-buffered saline.

S. Majumder, A. Muley, G.K. Kolluru, S. Saurabh, K. Tamilarasan, S. Chandrasekhar, H.B. Reddy, and S. Chatterjee. ${ }^{1}$ Vascular Biology Lab, Life Sciences, AU-KBC Research Centre, MIT Campus, Anna University, Chennai, Tamil Nadu 600044, India.

S. Purohit. Center for Biotechnology and Genomic Medicine, Medical College of Georgia, Augusta, GA 30912, USA.

${ }^{1}$ Corresponding author (e-mail: soovro@yahoo.ca). 
Fig. 1. (a) Assessment of the toxic dose of cadmium (Cd) in endothelial cells (ECs). A cell viability assay with trypan blue was performed to determine the $\mathrm{LD}_{50}$ of $\mathrm{Cd}$ (in the form of $\mathrm{CdCl}_{2}$ ). Blue staining indicates dead cells. Cells were treated for $8 \mathrm{~h}$ with concentrations of $\mathrm{CdCl}_{2}$ (ranging from 0 to $1000 \mu \mathrm{mol} / \mathrm{L}$ ), after which they were stained with $0.4 \mathrm{mg} / \mathrm{mL}$ trypan blue and incubated for $10-15 \mathrm{~min}$. Once staining was complete, the stained cells for each $\mathrm{CdCl}_{2}$ treatment were counted and the numbers plotted as percentages of dead cells. The observations suggested that $100 \mu \mathrm{mol} / \mathrm{L}$ is the $\mathrm{LD}_{50}$ of $\mathrm{Cd}$ for ECs. Each point on the graph represents 300 cells. *, Significantly different from control (cells not treated with $\mathrm{Cd}$ ) $(p \leq 0.05)$. (b) Measurement of nitric oxide (NO) production by ECs following Cd treatment. NO production by ECs was measured with a Griess assay. ECs were treated with different doses of $\mathrm{CdCl}_{2} \mathrm{ranging}$ from 0 to $1000 \mathrm{nmol} / \mathrm{L}$. $\mathrm{NO}$ generation reduced when the cells were treated with $\geq 100 \mathrm{nmol} / \mathrm{L} \mathrm{CdCl}_{2}$. The results suggest that Cd affects endothelial NO production in a dose-dependent manner. *, Significantly different from control cells $(p<0.05)$. (c) Temporal effect of Cd on EC NO production. NO production was measured with a Griess assay. ECs were treated with $100 \mathrm{nmol} / \mathrm{L} \mathrm{CdCl}_{2}$ for different time periods. NO generation reduced when the cells were treated with $100 \mathrm{nmol} / \mathrm{L} \mathrm{CdCl}_{2}$ for $4-8 \mathrm{~h}$. The results suggest that $\mathrm{Cd}$ affects endothelial $\mathrm{NO}$ production in a timedependent manner, particularly within 4-6 h. **, Significantly different from control $(p<0.001)$.

(Zawadzka et al. 1989). A tobacco addict smoking 20 cigarettes daily absorbs 2-4 $\mu \mathrm{g} \mathrm{Cd}$ each day and accumulates $0.5 \mathrm{mg} \mathrm{Cd}$ in a year (Massadeh et al. 2005; Oldereid et al. 1994).

Efforts have been made to understand the mechanisms of action of Cd toxicity, which causes multiple respiratory disorders, acute pneumonitis, emphysema (Nemery 1990; Oberdorster 1986), and impaired endothelium-dependent vasodilation of different vessels (Barua et al. 2001). Although a score of population studies and experimental works shows that $\mathrm{Cd}$ impairs cardiovascular health, the cellular and molecular mechanisms of Cd-mediated cardiovascular abnormalities have not yet been explored. $\mathrm{Cd}$ is known to affect the vascular tone of blood vessels and blood pressure (Baranski et al. 1983), and it is evident that Cd exposure produces hypertension in rats (Puri 1999). One of the biophysical explanations of $\mathrm{Cd}$-associated hypertension is that $\mathrm{Cd}$ replaces zinc, thereby contributing to the brittleness and hardness of arteries, which in turn causes hypertension (Chisolm and Handorf 1985). The work of Demontis et al. (1998) demonstrated that Cd affects mean arterial blood pressure in hypertensive rats by increasing both the alpha and beta isoforms of PKC (protein kinase C) in both SHR and WKY vascular smooth muscle cells. Kolluru et al. (2006) found that micromolar concentrations of $\mathrm{Cd}$ led to endothelial dysfunction by blocking eNOS activity. In this context, there is clear evidence that low and chronic exposure of vascular systems to $\mathrm{Cd}$ impairs vascular health (Navas-Acien et al. 2004). We hypothesize that low-level exposure to $\mathrm{Cd}$ attenuates eNOS activation by disrupting the phosphorylation pattern of eNOS. In this work, we partially dissect the mechanism of Cd-dependent eNOS inactivation.

\section{Materials and methods}

\section{Materials}

Dulbecco's modified Eagle's medium (DMEM) was purchased from Hi-Media (Mumbai, India). FBS was purchased from Invitrogen Life technologies (www.invitrogen.com). Diethylamine NONOate (DEAN) was purchased from EMD Biosciences, Inc. (www.emdbiosciences.com). Antibodies were purchased from Calbiochem, EMD Chemicals Inc. $\mathrm{CdCl}_{2}$ was purchased from Hi-Media, and used as the source of $\mathrm{Cd}$. All other chemicals were of reagent grade and were obtained commercially.

\section{Cell culture}

An immortalized endothelial hybrid cell line, EAhy926, was obtained from Dr. C.J.S. Edgell (the University of North. Carolina at Chapel Hill, Chapel Hill, N.C., USA), and was cultured in DMEM supplemented with 10\% FBS $(v / v), 1 \%$ penicillin-streptomycin $(w / v)$.

\section{NO estimation}

Endothelial cells (ECs) were incubated for $4 \mathrm{~h}$ with $\mathrm{CdCl}_{2}$ at $37{ }^{\circ} \mathrm{C}$ and $5 \% \mathrm{CO}_{2}$. NO was measured with a Griess assay protocol, described elsewhere (Nims et al. 1996).

\section{Wound healing assay}

We used the wound healing method to assess cell migration. EAhy926 cells $\left(10^{6}\right)$ in 2 mL DMEM - 10\% FBS were seeded in a $35 \mathrm{~mm}$ dish. When the cells reached confluence $24 \mathrm{~h}$ later, scratching the monolayer with a $1 \mathrm{~mm}$ wide sterile plastic scraper made a linear wound. As per the experimental protocol described elsewhere (Staton et al. 2004), cells were washed with PBS and treated with $\mathrm{Cd}$ (in the form of $\mathrm{CdCl}_{2}$ ) at concentrations ranging from 0 to $1 \mu \mathrm{mol}$ $\mathrm{CdCl}_{2} / \mathrm{L}$. and incubated for $8 \mathrm{~h}$. Bright-field images were taken at $4 \times$ magnification under an inverted bright field microscope. The rate of wound healing was quantified from the images using Scion Image alpha release 4.0 3.2 and Adobe Photoshop 6.0.

\section{MTT assay}

EAhy926 cells are grown to about $70 \%$ confluence in 24 well plates. The cells were then subjected to $\mathrm{Cd}$ treatment for $8 \mathrm{~h}$. After an $8 \mathrm{~h}$ incubation period, MTT was added to the media for a final concentration of $0.2 \mu \mathrm{g} / \mathrm{mL}$. After $2 \mathrm{~h}$ incubation with MTT, cells were subjected to isopropyl alcohol treatment. Isopropyl alcohol lysed the cells to release MTT-based colour products from the cells. The OD of the colour products was measured at $575 \mathrm{~nm}$ by using a Varian Cary 4000 UV-Vis spectrophotometer.

\section{Egg yolk angiogenesis assay}

Fourth day incubated eggs were collected from the Poultry Research Station, (Nandanam, Chennai, India). Eggs were broken and gently plated on a cellophane bed in Petri dishes under sterile conditions. $\mathrm{CdCl}_{2}$ discs (0-5 $\mu \mathrm{mol} / \mathrm{L})$ were then placed on the egg yolks, which were incubated for another $12 \mathrm{~h}$. Images were taken at a $20 \times$ magnification using a Nikon CoolPix camera adapted to a 
(a)
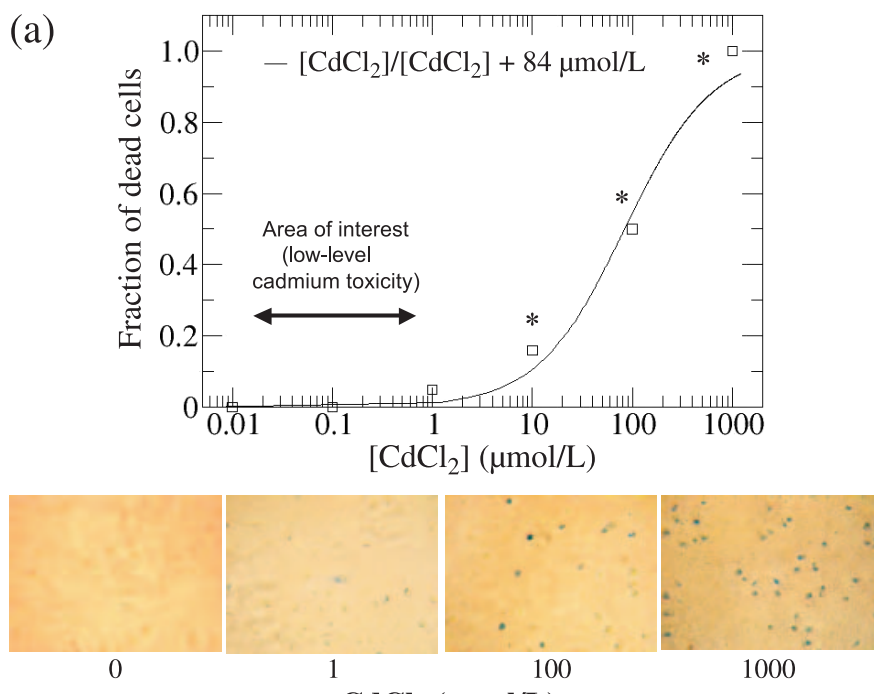

(b)

$\mathrm{CdCl}_{2}(\mu \mathrm{mol} / \mathrm{L})$
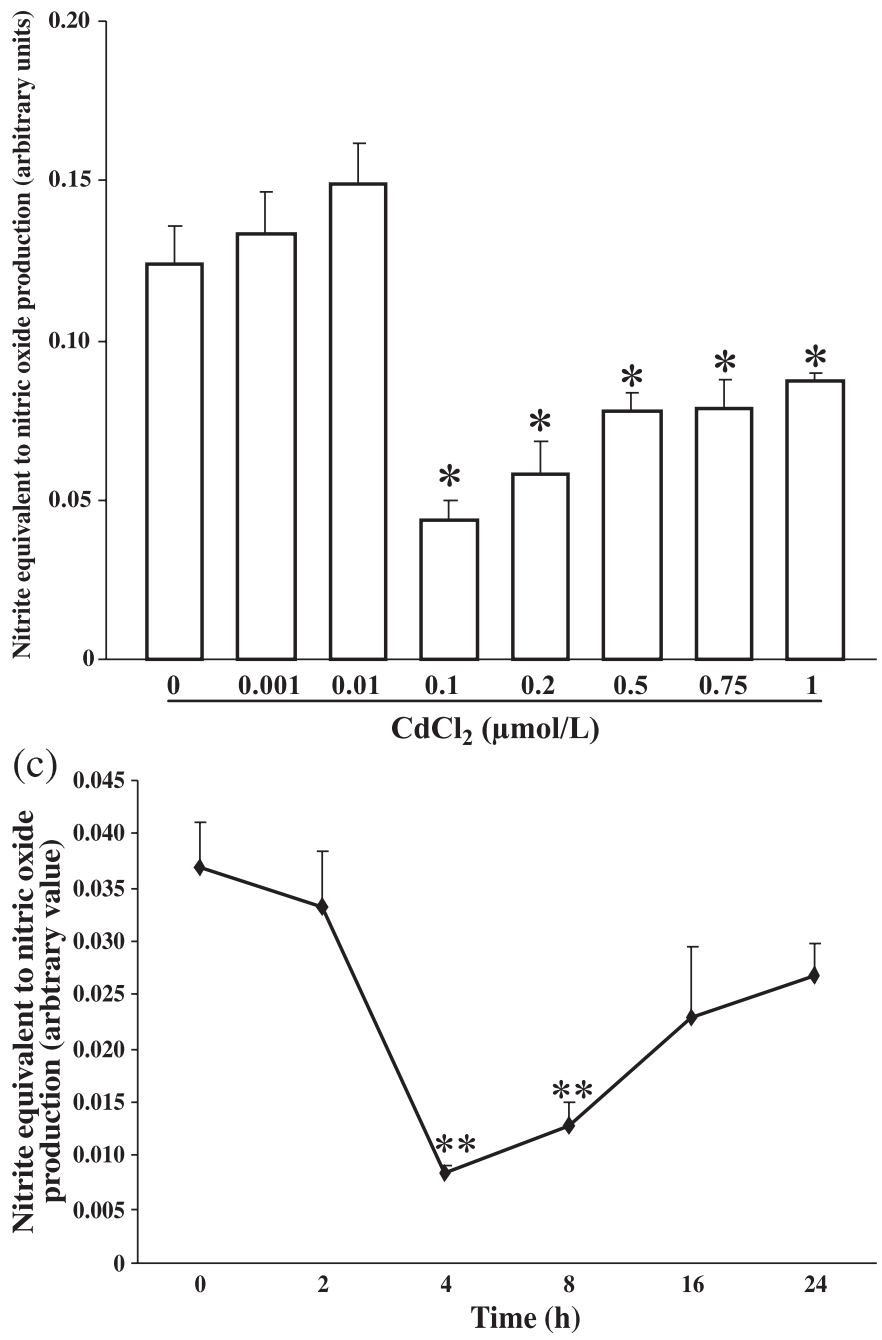

stereo-microscope after 0,6 , and $12 \mathrm{~h}$ of incubation. The quantification of angiogenesis was performed by using Scion Image alpha release 4.0 3.2 and Adobe Photoshop 7.0.

\section{Cell viability assay}

EAhy926 cells were grown to about $60 \%$ confluence in a
24 well plate. The cells were then subjected to Cd treatment for $4 \mathrm{~h}$. Trypan blue $(0.4 \mathrm{mg} / \mathrm{mL})$ was added to the media, and the cells were incubated for another $15 \mathrm{~min}$. After this incubation period, the media was removed and $1 \times$ PBS was added to all the wells. The number of cells with a blue nucleus were counted under a microscope. 
Fig. 2. (a) Cadmium (Cd) inhibits wound healing of endothelial cells (ECs). EC monolayers were wounded by scratching the monolayer surfaces, and then treated with $\mathrm{CdCl}_{2}$ for $8 \mathrm{~h}$. ECs treated with either 100 or $200 \mathrm{nmol} / \mathrm{L} \mathrm{CdCl}_{2}$ healed more slowly compared with the control cells. The result suggest that Cd blocks EC wound healing. *, Significantly different from control $(p<0.05)$. (b) Withdrawal of Cd from the media reverses Cd-mediated effects on ECs. EC monolayers were wounded by scratching the monolayer surfaces, and then subjected to Cd treatment for $4 \mathrm{~h}$. ECs treated with either 100 or $200 \mathrm{nmol} / \mathrm{L} \mathrm{CdCl}_{2}$ for up to $4 \mathrm{~h}$ healed more slowly compared with the control cells. Cells were then washed with PBS and further incubated with fresh DMEM for $6 \mathrm{~h}$. The inhibitory effect of $\mathrm{Cd}$ on EC wound healing was reversedwithin $4 \mathrm{~h}$ of washing post-treatment. *, Significantly different from control cells $(p<0.05)$.
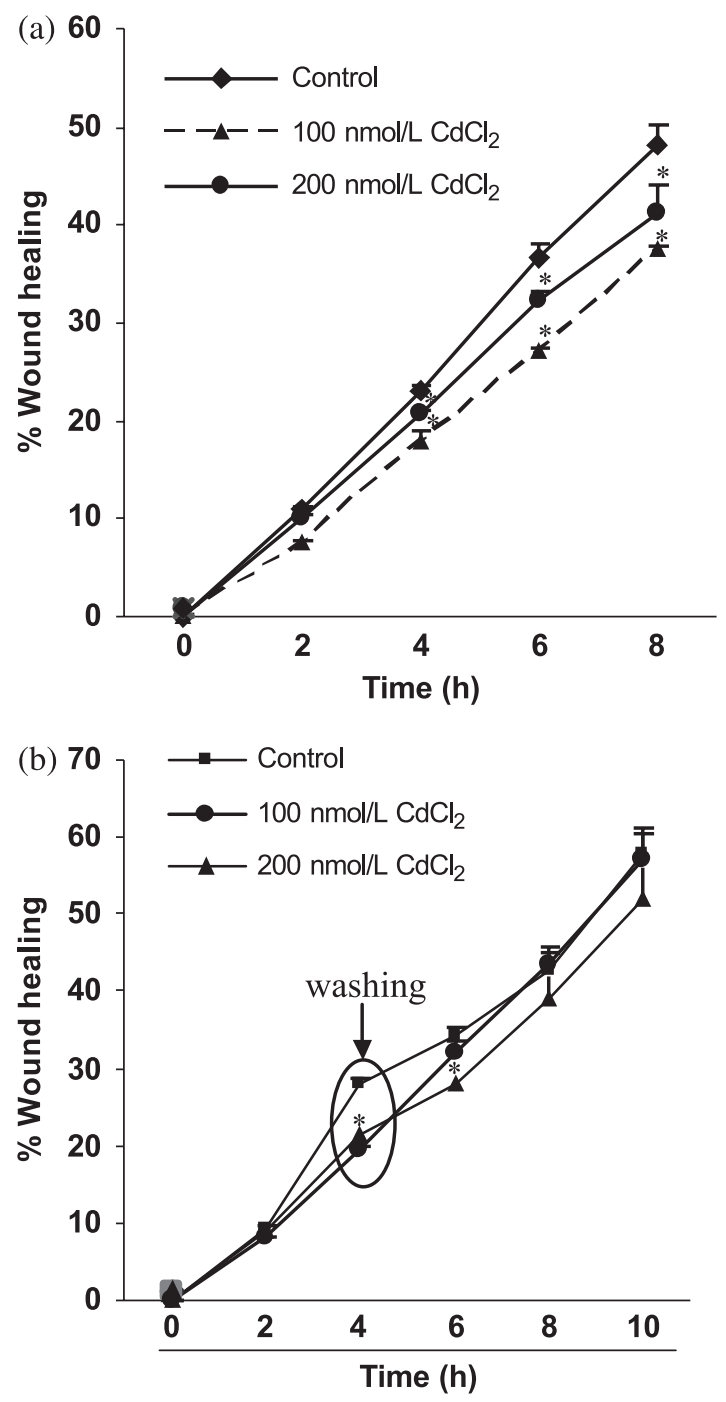

\section{Immunofluorescence}

These studies were carried out on EAhy926 cells in 12 well plates using the cold paraformaldehyde - Triton X-100 procedure (Mukhopadhyay et al. 2006; Shah et al. 2005). Cells were incubated at $4{ }^{\circ} \mathrm{C}$ overnight with rabbit polyclonal antibodies (dilution, 1:1000) against phospho-eNOS. Next, corresponding goat anti-rabbit secondary antibodies
Fig. 3. (a) Cadmium (Cd) blocks migration of endothelial cells (ECs). EC monolayers were wounded by scratching the monolayer surfaces, and then treated with $\mathrm{CdCl}_{2}$ and $10 \mu \mathrm{g} / \mathrm{mL}$ 5-fluoro uracil (5-FU) for $4 \mathrm{~h}$. Control sets both with and without 5-FU showed a significant difference in wound healing after $4 \mathrm{~h}$, and the same result was observed for cells that had been treated with $\mathrm{CdCl}_{2}$ (with and without 5-FU). The results suggest that $\mathrm{Cd}$ inhibits $\mathrm{EC}$ wound healing by blocking EC migration rather than proliferation. *, Significantly different between control 5-FU treated cells and control cells, between cells treated with $100 \mathrm{nmol} / \mathrm{L} \mathrm{5-FU}$ and $100 \mathrm{nmol} / \mathrm{L}$ $\mathrm{CdCl}_{2}$ alone, and between cells treated with $200 \mathrm{nmol} / \mathrm{L} \mathrm{5-FU}$ and $200 \mathrm{nmol} / \mathrm{L} \mathrm{CdCl}_{2}$ alone $(p<0.05)$. (b) MTT assay for mitochondrial succinate dehydrogenase activity of ECs treated with $\mathrm{CdCl}_{2}$. EC mitochondrial succinate dehydrogenase activity was determined with an MTT assay. Cells were subjected to Cd treatment for $4 \mathrm{~h}$ and then incubated with MTT for $2 \mathrm{~h}$. The OD of the colour metabolite was measured at $575 \mathrm{~nm}$. There was a significant decrease in MTT-based colour product formation by $\mathrm{CdCl}_{2}$-treated ECs. *, Significantly different from control cells $(p<0.05)$.
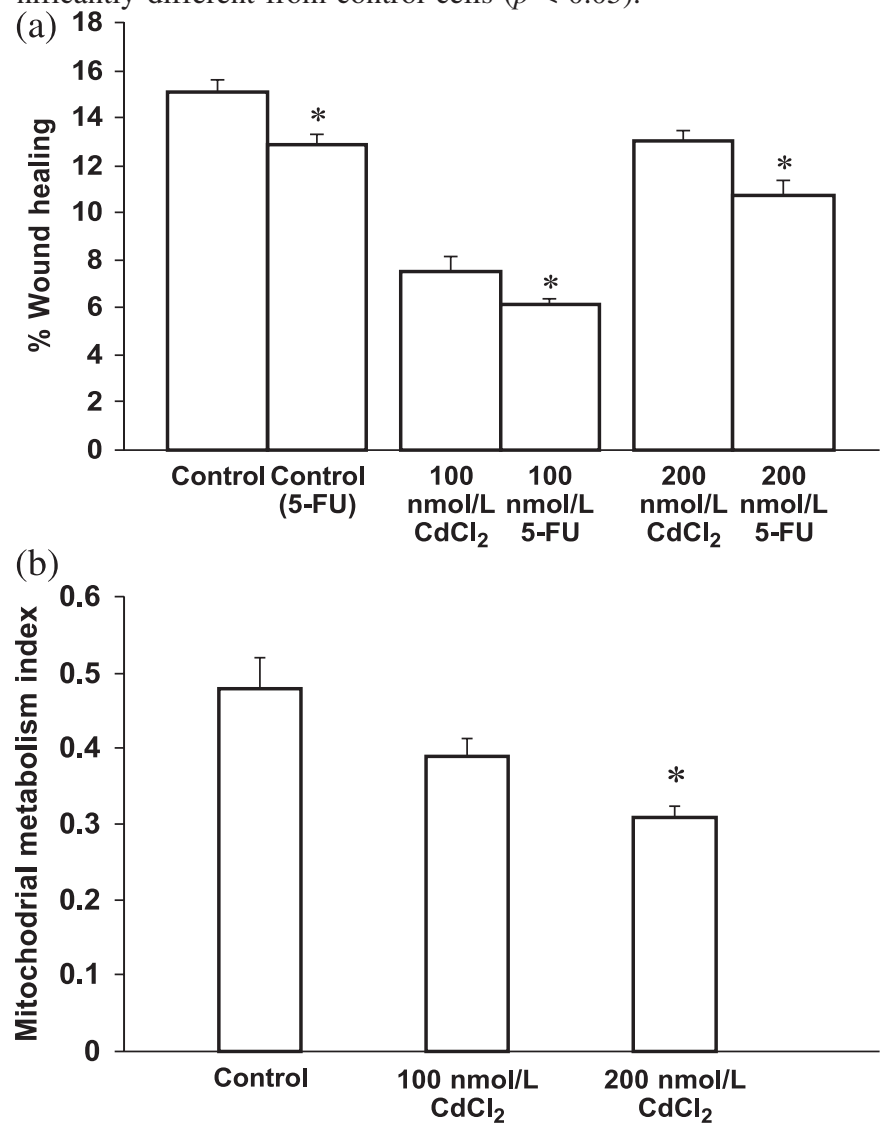

(dilution, 1:2000), tagged with fluorescein isothiocyanate, was used. Images were collected using a Nikon epifluorescence microscopy system equipped with a CCD camera loaded with black and white film.

\section{Western blot analyses of proteins}

Protein sample electrophoresis was performed by SDSPAGE using $10 \%$ polyacrylamide gels, as described elsewhere (Nakashima et al. 1999; Sehgal et al. 2002; Shah et al. 2002), and transferred onto a nitrocellulose membrane 
Fig. 4. (a) Cadmium (Cd) blocks angiogenesis in the egg yolk model in a dose-dependent manner. Fourth day incubated chicken eggs were broken and the entire contents transferred into a sterile Petri dish. Next, the vascular bed was incubated with different concentrations of $\mathrm{CdCl}_{2}$ soaked in sterilized paper discs and placed on the vascular bed for $12 \mathrm{~h}$. It is evident from the representative images that up to $500 \mathrm{nmol} / \mathrm{L} \mathrm{CdCl}_{2}$ inhibited angiogenesis, and higher concentrations of $\mathrm{CdCl}_{2}$ not only inhibited angiogenesis, but also destroyed preformed blood vessels. $(b)$ The inhibition of blood vessel formation was estimated by counting the number of red pixels using an analytical module of Image $J$ software. The red pixel count for cells treated with 100 and $500 \mathrm{nmol} / \mathrm{L} \mathrm{CdCl} \mathrm{C}_{2}$ remained unchanged, whereas the count decreased in cells treated with higher concentrations of $\mathrm{CdCl}_{2}$. ${ }^{*}$, Significantly different from cells at $0 \mathrm{~h}$ of treatment $(p<0.05)$. $(c) \mathrm{Cd}$ inhibited angiogenesis, whereas DEAN (diethylamine NONOate) alone induced angiogenesis (black arrows). DEAN administration, along with $\mathrm{Cd}$, restored the inhibitory effect of $\mathrm{Cd}$ on angiogenesis in the egg yolk vascular bed model. (d) The recovery of blood vessel formation was estimated by counting the number of red pixels using an analytical module of Image $\mathrm{J}$ software. The red pixel count for cells treated with $\mathrm{Cd}$ remained unchanged, whereas that of cells treated with $\mathrm{DEAN}+\mathrm{CdCl}_{2}$ was significantly higher. *, Significantly different from cells at $0 \mathrm{~h}$ of treatment $(p<0.05)$.

(a)

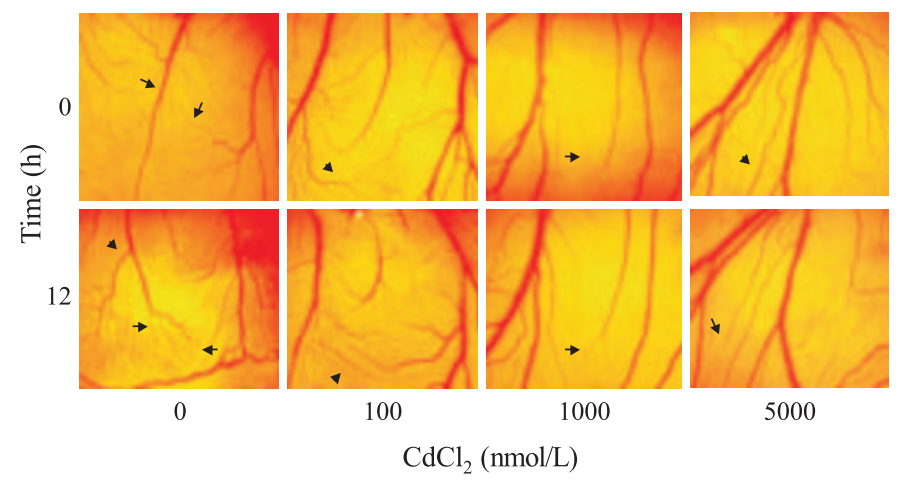

(c)

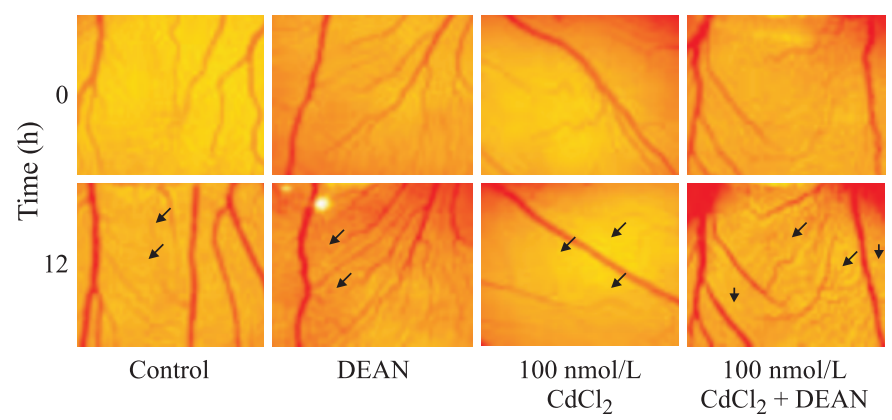

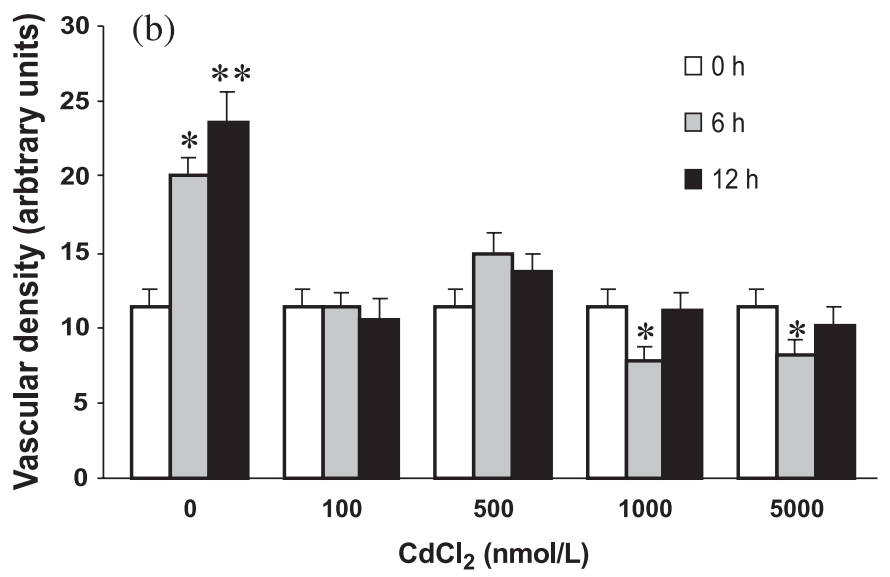

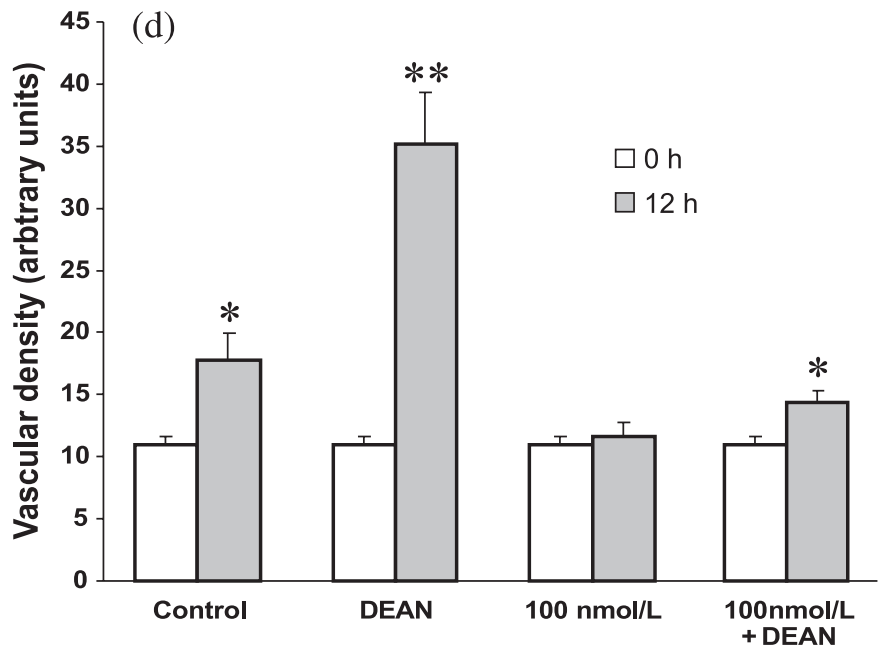

Results

Assessment of Cd toxicity in ECs

Our interest is to study the effect of a low dose of $\mathrm{Cd}$ on the control of vascular function, particularly in ECs. To ensure that the dose of $\mathrm{Cd}$ used in this study was within an apparently safe range, i.e., a range of concentrations that do not produce any adverse effect on cells and cellular metabolism, we performed a viability assay to determine the $\mathrm{LD}_{50}$ of $\mathrm{Cd}$ in ECs. Cells were treated with concentrations ranging from 0 to $1000 \mu \mathrm{mol} / \mathrm{L} \mathrm{CdCl}_{2}$ for $8 \mathrm{~h}$ followed by staining with $0.4 \mathrm{mg} / \mathrm{mL}$ trypan blue. The fraction of dead cells was obtained by counting the number of cells with a blue coloured nucleus. A plot of the percentage of dead cells vs $\mathrm{CdCl}_{2}$ concentration is shown in Fig. $1 a$. We did not observe a significant number of dead cells in the culture me- 
Fig. 5. Cadmium (Cd) inhibits nitric oxide (NO) production in a calcium-independent manner. Endothelial cells (ECs) were treated with $\mathrm{CdCl}_{2}$ alone, with a combination of $\mathrm{CdCl}_{2}+$ calcium $(500 \mu \mathrm{mol} / \mathrm{L})$, with a combination of $\mathrm{Cd}+$ the calcium channel blocker verapamil (100 s $\mu \mathrm{mol} / \mathrm{L})$. After $4 \mathrm{~h}$, NO production by ECs was measured with a Griess assay. The results show that treatment with $\mathrm{CdCl}_{2}$ alone inhibited $\mathrm{NO}$ production, whereas treatment with the combinations $\mathrm{CdCl}_{2}+$ calcium or $\mathrm{CdCl}_{2}+$ verapamil did not alter NO production by treated ECs compared with that by control cells. **, Significantly different from cells treated with $\mathrm{CdCl}_{2}(p<$ $0.001) ;++$, significantly different from control cells $(p<0.01)$.

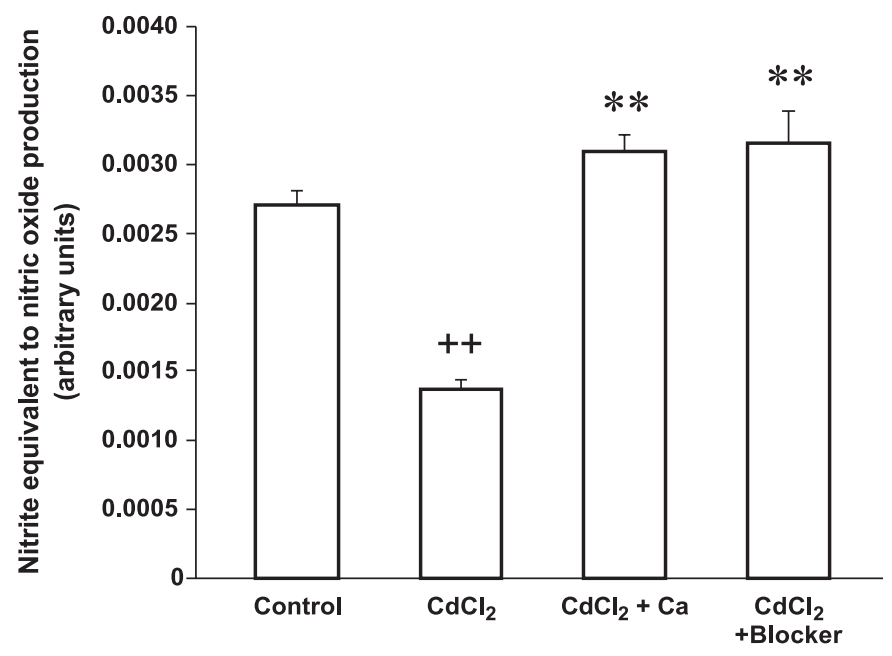

dium containing $0,0.01$, or $0.1 \mu \mathrm{mol} / \mathrm{L} \mathrm{CdCl}_{2}$. There were marginal increases of $5 \%$ and $16 \%$ in dead cells when the culture contained 1 and $10 \mu \mathrm{mol} / \mathrm{L} \mathrm{CdCl}_{2}$, respectively. Fifty percent of the total cell population was viable after treatment with $100 \mu \mathrm{mol} / \mathrm{L} \mathrm{CdCl}_{2}$, whereas the cell population was completely unviable after treatment with $1000 \mu \mathrm{mol} / \mathrm{L}$ $\mathrm{CdCl}_{2}$. These observations suggest that $100 \mu \mathrm{mol} / \mathrm{L}$ is the $\mathrm{LD}_{50}$ of $\mathrm{Cd}$ for ECs (Fig. 1a). The data fit quite well (solid line) with a $K_{\mathrm{d}}$ of $84 \mu \mathrm{mol} / \mathrm{L}$ and a Hill coefficient of 1 . This value of $K_{\mathrm{d}}$ is consistent with that for $\mathrm{CdCl}_{2}$ used as a calcium channel block and is compatible with data on the effects of $\mathrm{CdCl}_{2}$ on the integrity of other endothelial parameters (Weidner and Sillman 1997). Regardless of of this value of $\mathrm{LD}_{50}$ for $\mathrm{Cd}$, the results of our assessment of $\mathrm{Cd}$ toxicity suggested that the concentration we used in our subsequent experiments was well within the apparent safe range, because it was almost 1000 -fold lower than the $\mathrm{LD}_{50}$ for $\mathrm{Cd}$.

\section{Effects of low Cd concentration on EC generation of NO}

We determined EAhy926 cell NO production in response to different doses of $\mathrm{CdCl}_{2}$ ranging from 0 to $1000 \mathrm{nmol} / \mathrm{L}$. No effect on NO production was observed when cells were treated with 1 and $10 \mathrm{nmol} / \mathrm{L} \mathrm{CdCl} \mathrm{Cl}_{2}$. Treatment of ECs with 100 and $200 \mathrm{nmol} / \mathrm{L} \mathrm{CdCl}_{2}$ caused a reduction in the production of NO by $70 \%$ and $57 \%$, respectively (Fig. 1b). Interestingly, increasing $\mathrm{CdCl}_{2}$ concentrations above $500 \mathrm{nmol} / \mathrm{L}$ reduced the impact of $\mathrm{Cd}$ on the inhibition of NO production to $30 \%$. We did not investigate this phenomenon further, but used $100 \mathrm{nmol} / \mathrm{L} \mathrm{CdCl}_{2}$ to further investigate the effects of ultra-low concentrations of $\mathrm{Cd}$ on endothelial cell NO production.
To elucidate further the temporal effect of $\mathrm{Cd}$ on NO production by ECs, EAhy926 cells were treated with $100 \mathrm{nmol} / \mathrm{L}$ of $\mathrm{CdCl}_{2}$, and $\mathrm{NO}$ production was monitored for $24 \mathrm{~h}$. Figure $1 c$ shows that a $100 \mathrm{nmol} / \mathrm{L}$ treatment of $\mathrm{EC}$ ensured significant $(p<0.001)$ reductions in $\mathrm{NO}$ of $72 \%$ and $61 \%$ after 4 and $8 \mathrm{~h}$, respectively, whereas no significant $(p>$ $0.05)$ inhibition resulted after shorter $(2 \mathrm{~h})$ or longer (16 and $24 \mathrm{~h}$ ) exposures to $\mathrm{Cd}$ (Fig. 1c). These results suggest that $\mathrm{Cd}$ exerts its effect on $\mathrm{NO}$ production in a time-dependent manner, and specifically, within 4-16 h.

\section{Effects of low concentrations of $\mathrm{Cd}$ on NO-mediated physiological function}

$\mathrm{NO}$ is one of the key regulators of migration and proliferation of ECs. Therefore, to determine the effect of $\mathrm{Cd}$ on endothelial function in relation to low NO production, a wound-healing assay was performed. Scratch wounds were created on monolayer cultures of EC. The rate of wound healing under different conditions was monitored at regular intervals for the next $8 \mathrm{~h}$. Marked drops in the rate of wound healing, $23 \%$ and $15 \%$, were observed in the cells treated with 100 and $200 \mathrm{nmol} / \mathrm{L} \mathrm{CdCl}_{2}$, respectively (Fig. 2a). No significant $(p>0.05)$ difference from the control (untreated) cells was observed after $2 \mathrm{~h}$ of treatment, although after $4 \mathrm{~h}$, a significant $(p<0.05)$ inhibition of wound healing was noted in cells exposed to $200 \mathrm{nmol} / \mathrm{L} \mathrm{CdCl}$. Further incubations of 6 and $8 \mathrm{~h}$ had significant $(p<0.05)$ effects on wound healing in cells treated with 100 and $200 \mathrm{nmol} / \mathrm{L}$ $\mathrm{CdCl}_{2}$.

To determine whether $\mathrm{Cd}$ withdrawn from the media is able to reverse the effect of $\mathrm{Cd}$ on $\mathrm{ECs}$, we washed $\mathrm{Cd}$ treated cells (for $4 \mathrm{~h}$ ) 3 times with $1 \times \mathrm{PBS}$, and incubated the cells with fresh Cd-free media for another $6 \mathrm{~h}$. The results (Fig. 2b) indicate that $\mathrm{Cd}$ removal restored the normal rate of wound healing in ECs within 2 and $4 \mathrm{~h}$ of washing post-treatment for 100 and $200 \mathrm{nmol} / \mathrm{L} \mathrm{CdCl}_{2}$, respectively.

\section{Low Cd concentrations inhibit EC migration}

The recovery of cell function in the wound healing experiments was due to a combined effect of EC migration and proliferation. To determine whether Cd-mediated inhibition of wound healing was due to the inhibition of migration or proliferation, we performed wound-healing experiments in the presence of 5-fluro uracil (5-FU), an anti-proliferative agent. The results of these experiments (Fig. 3a) show that 5-FU-dependent inhibition of wound healing is insensitive to $\mathrm{Cd}$ treatment. Control cells showed $14 \%$ inhibition of wound healing with 5-FU treatment. This was similar to that of cells exposed to 100 and $200 \mathrm{nmol} / \mathrm{L} \mathrm{Cd}$ for $8 \mathrm{~h}$, which showed $19 \%$ and $16 \%$ inhibition of wound healing, respectively, with 5-FU. This observation suggests that $\mathrm{Cd}$ mediated inhibition of wound healing is based on inhibition of cellular migration rather than that of proliferation.

\section{Low Cd concentrations inhibit mitochondrial succinate dehydrogenase activity}

An MTT assay was performed to assess the activity of succinate dehydrogenase, an indicator of proliferation, in EC cells treated with $\mathrm{CdCl}_{2}$. MTT assays produce a colored product, whose intensity depends on mitochondrial dehydrogenase activity. EC cells were treated with 100 and 
Fig. 6. Cadmium (Cd) inhibits eNOS by blocking phosphorylation of eNOS. (a) Immunofluoroscence was carried out on endothelial cells (ECs) in 12-well plates using the cold paraformaldehyde Triton X-100 protocol (Mukhopadhyay et al. 2006; Shah et al. 2005). Cells were incubated at $4{ }^{\circ} \mathrm{C}$ overnight with rabbit polyclonal antibodies (dilution, 1:1000) against phospho-eNOS. Next, corresponding goat anti-rabit secondary antibodies (dilution, 1:2000), tagged with FITC (fluorescein isothiocyanate) was used to immunodetect the phosphorylated eNOS population. Images were acquired with a Nikon epifluorescence microscopy system equipped with a CCD camera loaded with black and white film. The total fluorescence intensity observed for the Cd-treated cells was lower than that for control cells. Further, the number of FITC-positive spots originating from antibodies bound to phophorylated spots was lower in Cd-treated cells compared with that in control cells. The results suggest that $\mathrm{Cd}$ blocks eNOS phosphorylation. $(b)$ Images in $a$ were analyzed with an analytical module of Image $\mathrm{J}$ software. The data suggest that Cd-treated cells fluoresced less than the control cells. *, Significantly different from the control cells $(p<0.05)$. (c) Protein samples were prepared from cells that were either treated or not treated with $\mathrm{CdCl}_{2}$. A Western blot analysis to determine eNOS expression and phosphorylation was performed using prepared protein samples. Immunodetection of phosphorylated eNOS proteins in the Western blot reveals that Cd blocks phosphorylation of eNOS, while total eNOS expression wasunchanged by Cd treatment.

$200 \mathrm{nmol} / \mathrm{L} \mathrm{CdCl}_{2}$ in a culture medium for $8 \mathrm{~h}$, and MTT was added to determine mitochondrial metabolism. Cd treatments of 100 and $200 \mathrm{nmol} / \mathrm{L} \mathrm{CdCl}_{2}$ resulted in $20 \%$ and $40 \%$ reductions in enzyme activity, respectively (Fig. 3b) The results indicate that succinate dehydrogenase was inhibited in mitochondria as a result of $\mathrm{Cd}$ challenge.

\section{Cd blocks angiogenesis in the egg yolk model in a dose-} dependent manner

The egg yolk vascular bed model is an angiogenesis model with which one can track and observe the formation of blood vessels. Fourth day fertilized eggs with semideveloped vascular beds were plated on Petri dishes and treated with different concentrations of $\mathrm{CdCl}_{2}$ ranging from $\mathrm{O}_{-}$ $5000 \mu \mathrm{mol} / \mathrm{L}$. Real-time tracking of the developing vascular beds demonstrated that $\mathrm{Cd}$ inhibited blood vessel formation in a dose-dependent manner (Fig. 4a). Figure $4 b$ summarizes the results for the area of vascular coverage after exposure to various $\mathrm{CdCl}_{2}$ concentrations at 6 and $12 \mathrm{~h}$. We note that $\mathrm{CdCl}_{2}$ concentrations up to $500 \mathrm{nmol} / \mathrm{L}$ specifically attenuated the formation of terminal capillaries, whereas higher concentrations, i.e., $\geq 1000 \mathrm{nmol} / \mathrm{L}$, destroyed blood vessels after $6 \mathrm{~h}$. This observation is supported by the results from cell-based assays, in which the maximum effect of $\mathrm{Cd}$ was seen within 4-8 h of treatment. In another set of experiments with the egg yolk model, a combination treatment of $\mathrm{Cd}$ and DEAN restored the effect of $\mathrm{Cd}$ on angiogenesis (Figs. $4 c$ and $4 d$ ), whereas $\mathrm{Cd}$ alone maintained its effect on angiogenesis.

\section{Cd inhibits NO production in a calcium-independent manner}

To determine whether the effect of $\mathrm{Cd}$ is dependent on (a)

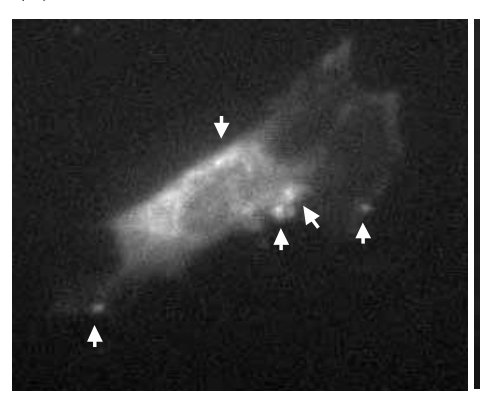

0

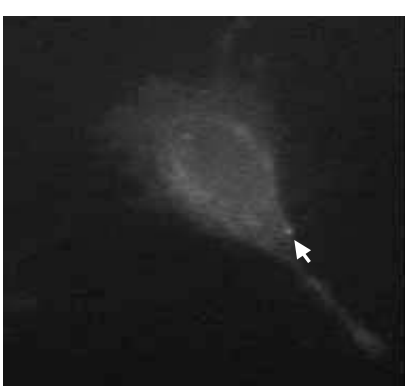

100 (b)

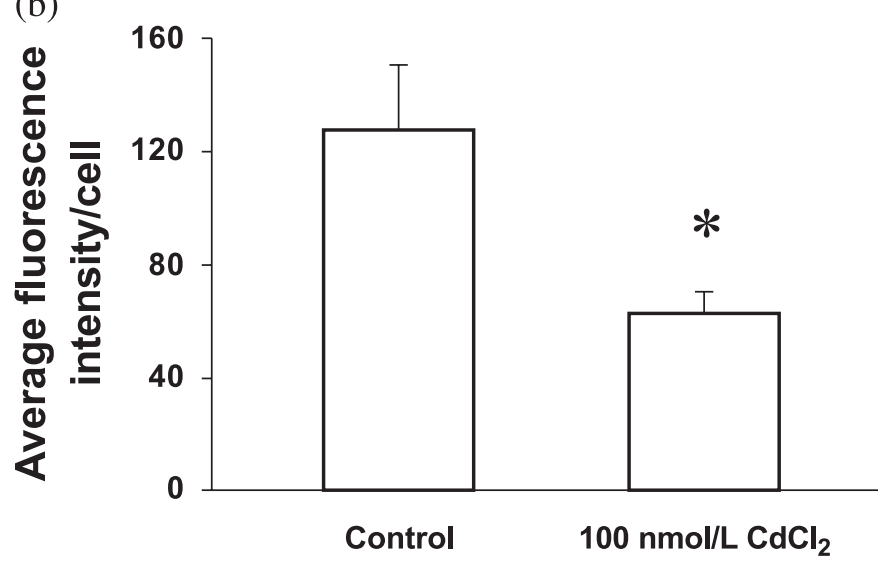

(c)
$\mathrm{CdCl}_{2}(\mathrm{nmol} / \mathrm{L})$

0

10

100

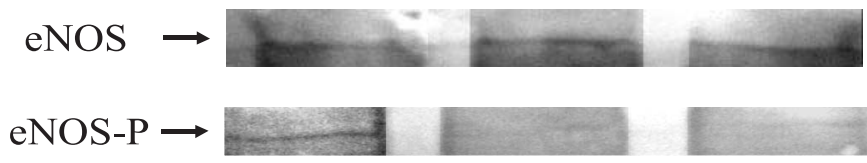

calcium, we measured NO after Cd treatment, along with verapamil and calcium. For the calcium treatment, cells were first exposed to a calcium ionophore $(1 \mu \mathrm{mol} / \mathrm{L})$, and after $5 \mathrm{~min}, 500 \mu \mathrm{mol} / \mathrm{L}$ was added. In all cases, the cells were treated with $\mathrm{CdCl}_{2}$ and then incubated for $4 \mathrm{~h}$. The results show that $\mathrm{Cd}$-mediated inhibition of $\mathrm{NO}$ production is a calcium-independent phenomenon. We observed that $\mathrm{Cd}$ in nanomolar concentrations attenuated NO production in ECs. When the cells were treated with the calcium channel blocker verapamil $(100 \mu \mathrm{mol} / \mathrm{L})$ along with $\mathrm{CdCl}_{2}$, we did not observe any further inhibition of $\mathrm{NO}$ production (Fig. 5). Thus, we infer that blocking calcium channels restricted $\mathrm{Cd}$ entry into the cells, which ultimately blunted Cd-dependent inhibition of NO production in ECs.

\section{Cd inhibits NO production by blocking eNOS phosphorylation}

We used immunofluroscence techniques to study the effect of $\mathrm{Cd}$ on eNOS phosphorylation. Cells were fixed using $2 \%$ paraformaldehyde and then probed with a primary antibody specific for phosphorylated eNOS. Overall, less fluo- 
rescence was observed in Cd-treated cells compared with that in control (untreated) cells. In control cells, the focal points of phosphorylated eNOS were observed under UV illumination, whereas $\mathrm{Cd}$ treatments abolished the phosphorylated eNOS population from both the perinulclear and plasma membrane regions (Figs. $6 a$ and $6 b$ ).

To semiquantify eNOS phosphorylation after $\mathrm{Cd}$ treatment, protein samples from cells either treated or not treated with $\mathrm{CdCl}_{2}$ were prepared, subjected to SDS-PAGE, and subsequently immunoblotted. The results suggest that $\mathrm{Cd}$ attenuates eNOS phosphorylation, even though the expression level of total eNOS remained unchanged after $\mathrm{Cd}$ treatment (Fig. 6c).

\section{Discussion}

The results of this study show that Cd blocks NO production via inactivation of eNOS (Figs. $6 a, 6 b$, and $6 c$ ). The work of Abu-Hayyeh et al. (2001) has shown that ECs respond to lower $\mathrm{Cd}$ concentrations compared with smooth muscle cells (Abu-Hayyeh et al. 2001). Their calculations revealed that the average $\mathrm{Cd}$ concentration in the medial layer of blood vessel is $7 \mu \mathrm{mol} / \mathrm{L}$ (Abu-Hayyeh et al. 2001). $\mathrm{Cd}$ is known to replace zinc and contributes to the brittleness and hardness of the arteries that is believed to cause hypertension (Chisolm and Handorf 1985). Skoczynska and Martynowicz (2005) demonstrated that rats poisoned with hypertensive doses of $\mathrm{Cd}$ showed diminished vascular response to L-NOARG, an inhibitor of NOS, by shifting the dose-response curve to the right. From these observations, we surmise that deposited $\mathrm{Cd}$, which remains 30 years after deposition in the blood vessel walls, may leach out of the wall in a low but in a chronic pattern. This assumption led us to test endothelial function under nanomolar doses of $\mathrm{Cd}$. It should be noted that the $\mathrm{Cd}$ concentrations we used here are about 10000 times lower than the $\mathrm{LD}_{50}$ of $\mathrm{Cd}$ for ECs (Fig. 1a). Our study shows that these ultra-low concentrations of $\mathrm{Cd}$ significantly reduce NO production from endothelial monolayers, and thereby impair endothelial functions (Figs. $1 b$ and $1 c$ ). Another important point is that $\mathrm{Cd}$ maximally attenuated NO production at the 4th $\mathrm{h}$ of treatments compared with that in the 8th h (Fig. 1c). Earlier studies showed that $\mathrm{Cd}$ is capable of metallothionein induction and gives peaks at the fourth $\mathrm{h}$ of induction (Caperna and Failla 1984; Margarita et al. 2001). Based on this information, we speculate that $\mathrm{Cd}$ is available for blocking $\mathrm{NO}$ production until metallothionein relocates active $\mathrm{Cd}$ from the cytosol to less active subcellular compartments. Subcellular trafficking of NOS also can be a determinate of $\mathrm{Cd}$ based NOS inactivation, which is associated with calcium-calmodulin interaction. It has been shown that $\mathrm{Cd}$ interferes with calcium-calmodulin complexation (Cheung 1984; Yuan et al. 2004). Therefore, subcellular relocalization of NOS modulates NOS-calmodulin-Cd interaction by placing NOS in less or more active compartments.

Earlier studies demonstrated that $\mathrm{Cd}$ introduces profound time- and dose-dependent alterations of phospholipid metabolism in bovine pulmonary artery ECs (Nelson et al. 1991), which in turn supports our results showing that $\mathrm{Cd}$ has a dose- and time-dependent effect on endothelial function, including angiogenesis (Figs. $4 a$ and $4 b$ ). A quantitative anal- ysis of the effect of $\mathrm{Cd}$ on EC proliferation and migration by Kishimoto et al. (2005) suggests that EC migration is susceptible to $\mathrm{Cd}$ cytotoxicity and that EC outgrowths are inhibited by $\mathrm{Cd}$, which in turn supports our observation that low concentrations of Cd block EC wound healing by blocking migration (Fig. 2a). However, the wound-healing process can be a summation of the effects of EC migration and proliferation. To determine the exact nature of $\mathrm{Cd}$ interference in EC monolayer wound healing, we used 5-FU to block cell proliferation. The results show that $\mathrm{Cd}$-mediated inhibition of wound healing is independent of proliferation (Fig. 3a). We proceeded to confirm this observation with an MTT assay to ensure that $\mathrm{Cd}$ did not impair proliferation. However, contrary to our expectation, the MTT assay showed a lower level of mitochondrial succinate dehydrogenase activity after $\mathrm{Cd}$ treatment (Fig. 3b). This observation led us to speculate that $\mathrm{Cd}$, at least at low concentrations, failed to reduce the number of viable cells by blocking succinate dehydrogenase; rather, it seems to have enhanced the number of viable cells by antagonizing apoptosis. In support of our observations, a previous finding by Gunawardana et al. (2006) demonstrated that Cd suppressed DNA laddering, nuclear condensation, procaspase-3 cleavage, caspase-8, caspase-9, and the release of cytochrome $c$ from mitochondria in rat mesangial cells. They concluded that $\mathrm{Cd}$ inhibits both intrinsic and extrinsic apoptotic pathways in renal mesangial cells (Gunawardana et al. 2006).

It has already been noted that $\leq 100 \mathrm{nmol} / \mathrm{L} \mathrm{Cd}$ can increase the incorporation of $\left[{ }^{3} \mathrm{H}\right]$ thymidine into the acidinsoluble fraction of growing bovine and rabbit aortic smooth muscle cells, but not into that of growing bovine aortic ECs (Fujiwara et al. 1998). Peereboom-Stegeman and Jongstra-Spaapen (1979) showed that the effects of injected $\mathrm{Cd}$ can be reversed even after prolonged incubation on the microcirculation in rat uterus. To determine whether the effects of low $\mathrm{Cd}$ concentration on ECs can be reversed, we performed wound-healing assays by washing cells after $4 \mathrm{~h}$ of $\mathrm{Cd}$ treatment. The results (Fig. 2b) suggest that the effects of $\mathrm{Cd}$ can indeed be reversed within $4 \mathrm{~h}$ of withdrawing $\mathrm{Cd}$ from the cells.

The involvement of NO in angiogenesis has been well documented (Ekmekcioglu et al. 2005). A recent study by $\mathrm{Yu}$ et al. (2005) using eNOS knockout mice suggests that endogenous eNOS-derived NO exerts direct effects on the preservation ofblood flow, thereby promoting arteriogenesis, angiogenesis, and mural cell recruitment to immature angiogenic sprouts. A study by Michaud et al. (2003) demonstrated that cigarette smoke, a source of $\mathrm{Cd}$ toxicity, impaired hypoxia-induced angiogenesis. Vascular endothelial growth factor (VEGF) is a dimeric protein that induces angiogenesis through binding to VEGF-receptor-2 tyrosine kinase (VEGFR2 TK) on the surface of ECs. Cd is also implicated in angiogenesis by inhibiting VEGFR2 TK (Parast et al. 1998). The present work is consistent with these earlier data, in that it shows that $100 \mathrm{nmol} / \mathrm{L} \mathrm{Cd}$ attenuates egg yolk angiogenesis at the capillary ends. However, a higher dose of $\mathrm{Cd}$ (in the millimolar range) possibly caused necrotic elimination of preformed blood vessels, as observed by trypan blue inclusion in the affected blood vessels (data not shown). The results of the endothelial cell viability assay 
with trypan blue also revealed that, in higher doses, $\mathrm{Cd}$ induced cell death in endothelial monolayers (Fig. 1a). These observations raise the question of whether $\mathrm{Cd}$-induced cell death in blood vessels is due to apoptosis. Recent work by Liu and Templeton (2007) highlights the observation that, at $10-20 \mu \mathrm{mol} / \mathrm{L}, \mathrm{Cd}$ initiates apoptosis in mesangial cells via CaMK-II dependent signaling. A score of earlier works have also showed that $\mathrm{Cd}$ induces apoptosis in various cell types, such as lymphoblastoid cells and osteoblasts (Coutant et al. 2006; Coonse et al. 2007).

Previous work by various groups has already shown that eNOS can be activated via 2 different pathways, the calcium-calmodulin pathway (Jagnandan et al. 2005) and the eNOS phosphorylation pathway (Sessa 2004; Fulton et al. 2001). In this study, we hypothesized that eNOS inactivation under conditions of low Cd stress is associated with eNOS phosphorylation, and thereby leads to endothelial dysfunction. In support of this hypothesis, the results in this work demonstrate that $100 \mathrm{nmol} / \mathrm{L}$ of $\mathrm{Cd}$ inactivates eNOS by blocking eNOS phosphorylation (Figs. $6 a, 6 b$, and $6 c$ ). At the same time, the results from Western blots show that eNOS expression is similar in both Cd-treated and untreated ECs (Fig. 6c). Further supporting this hypothesis is the inhibitory effect of $\mathrm{Cd}$ uptake on basal $\mathrm{NO}$ production by ECs (Fig. 5). Interestingly, the co-application of verapamil or calcium along with $\mathrm{CdCl}_{2}$ maintained the level of basal NO production. It has been shown that calcium hinders $\mathrm{Cd}$ uptake by cells (Hinkle et al. 1987; Reeves et al. 2005). Thus, the effects of $\mathrm{Cd}$ on NO production are apparently at least partially due to transmembrane influx of $\mathrm{Cd}$ and enhanced subcellular $\mathrm{Cd}$ pool. Overall, the data suggest that Cd-mediated inhibition of NO production results from the blocking of eNOS phosphorylation.

In summary, this work partially elucidated the mechanism of eNOS inactivation by low levels of $\mathrm{Cd}$ by showing that the effects of $\mathrm{Cd}$ are due to a decrease in $\mathrm{NO}$ production by ECs. This study indicates that low levels of $\mathrm{Cd}$ induce endothelial dysfunction, and we attribute this effect to the blocking of eNOS phosphorylation. A further probe into the sitespecific phosphorylation patterns of eNOS and their interplay with $\mathrm{Cd}$, which is presently underway, will unravel the mechanism of low-level $\mathrm{Cd}$ perturbations in vascular diseases.

\section{Acknowledgements}

This study was financially supported by an Indian Council of Medical Research (ICMR) grant to S.C. (5/8/4/9(Env)/ 2005-NCD-I). S.P. is a recipient of a JDRF Advanced Postdoctoral fellowship (JDRF No. 10-2006-792). This work was partially supported by a Wellcome Trust Grant (No. 070069).

\section{References}

Abu-Hayyeh, S., Sian, M., Jones, K.G., Manuel, A., and Powell, J.T. 2001. Cadmium accumulation in aortas of smokers. Arterioscler. Thromb. Vasc. Biol. 21: 863-867. PMID:11348888.

Baranski, B., Opacka, J., Wronska-Nofer, T., Trzcinka-Ochocka, M., and Sitarek, K. 1983. Effect of Cd on arterial blood pressure and lipid metabolism in rats. Toxicol. Lett. 18: 245-250. doi:10. 1016/0378-4274(83)90101-7. PMID:6665796.

Barua, R.S., Ambrose, J.A., Eales-Reynolds, L.J., DeVoe, M.C.,
Zervas, J.G., and Saha, D.C. 2001. Dysfunctional endothelial nitric oxide biosynthesis in healthy smokers with impaired endothelium-dependent vasodilatation. Circulation, 104: 19051910. doi:10.1161/hc4101.097525. PMID:11602492.

Bokori, J., and Fekete, S. 1995. Complex study of the physiological role of Cd. I. Cd and its physiological role. Acta Vet. Hung. 43: 3-43. PMID:7625291.

Caperna, T.J., and Failla, M.L. 1984. Cd metabolism by rat liver endothelial and Kupffer cells. Biochem. J. 221: 631-636. PMID:6477490.

Cheung, W.Y. 1984. Calmodulin: its potential role in cell proliferation and heavy metal toxicity. Fed. Proc. 43: 2995-2999. PMID:6389184.

Chisolm, J.C., and Handorf, C.R. 1985. Zinc, Cd, metallothionein, and progesterone: do they participate in the etiology of pregnancy induced hypertension? Med. Hypotheses, 17: 231-242. doi:10.1016/0306-9877(85)90128-8. PMID:3900651.

Coonse, K.G., Coonts, A.J., Morrison, E.V., and Heggland, S.J. 2007. Cd induces apoptosis in the human osteoblast-like cell line Saos-2. J. Toxicol. Environ. Health A, 70: 575-581. doi:10. 1080/15287390600882663. PMID:17365611.

Coutant, A., Lebeau, J., Bidon-Wagner, N., Levalois, C., Lectard, B., and Chevillard, S. 2006. Cd-induced apoptosis in lymphoblastoid cell line: involvement of caspase-dependent and -independent pathways. Biochimie, 88: 1815-1822. doi:10.1016/j. biochi.2006.09.018. PMID:17069945.

Demontis, M.P., Varoni, M.V., Volpe, A.R., Emanueli, C., and Madeddu, P. 1998. Role of nitric oxide synthase inhibition in the acute hypertensive response to intracerebroventricular $\mathrm{Cd}$. Br. J. Pharmacol. 123: 129-135. doi:10.1038/sj.bjp.0701573. PMID: 9484863.

Ekmekcioglu, S., Tang, C.H., and Grimm, E.A. 2005. NO news is not necessarily good news in cancer. Curr. Cancer Drug Targets, 5: 103-115. doi:10.2174/1568009053202072. PMID:15810875.

Fujiwara, Y., Watanabe, S., and Kaji, T. 1998. Promotion of cultured vascular smooth muscle cell proliferation by low levels of Cd. Toxicol. Lett. 94: 175-180. doi:10.1016/S0378-4274(98) 00005-8. PMID:9609320.

Fulton, D., Gratton, J.P., and Sessa, W.C. 2001. Post-translational control of endothelial nitric oxide synthase: why isn't calcium/ calmodulin enough? J. Pharmacol. Exp. Ther. 299: 818-824. PMID:11714864.

Gunawardana, C.G., Martinez, R.E., Xiao, W., and Templeton, D.M. 2006. Cd inhibits both intrinsic and extrinsic apoptotic pathways in renal mesangial cells. Am. J. Physiol. Renal Physiol. 290: F1074-F1082. doi:10.1152/ajprenal.00067.2005. PMID:16263807.

Hinkle, P.M., Kinsella, P.A., and Osterhoudt, K.C. 1987. Cd uptake and toxicity via voltage-sensitive calcium channels. J. Biol. Chem. 262: 16333-16337. PMID:2445745.

Jagnandan, D., Sessa, W.C., and Fulton, D. 2005. Intracellular location regulates calcium-calmodulin-dependent activation of organelle-restricted eNOS. Am. J. Physiol. Cell Physiol. 289: C1024-C1033. doi:10.1152/ajpcell.00162.2005. PMID: 15917301.

Kishimoto, T., Oguri, T., Yamabe, S., and Tada, M. 2005. The role of thymidylate synthase and dihydropyrimidine dehydrogenase in resistance to 5- uorouracil in human lung cancer cells. Lung Cancer, 49: 345-351. doi:10.1016/j.lungcan.2005.05.003. PMID:15993511.

Kolluru, G.K., Tamilarasan, K.P., Geetha Priya, S., Durgha, N.P., and Chatterjee, S. 2006. Cd induced endothelial dysfunction: consequence of defective migratory pattern of endothelial cells in association with poor nitric oxide availability under $\mathrm{Cd}$ chal- 
lenge. Cell Biol. Int. 30: 427-438. doi:10.1016/j.cellbi.2006.02. 002. PMID:16616865.

Liu, Y., and Templeton, D.M. 2007. Cd activates CaMK-II and initiates CaMK-II-dependent apoptosis in mesangial cells. FEBS Lett. 581: 1481-1486. doi:10.1016/j.febslet.2007.03.003. PMID: 17367784.

Margarita, D., Apostolova, S.C., Chakrabarti, S., and Cherian, M.G. 2001. High-glucose-induced metallothionein expression in endothelial cells: an endothelin-mediated mechanism. Am. J. Physiol. Cell Physiol. 281: C899-C907. PMID:11502567.

Massadeh, A.M., Alali, F.Q., and Jaradat, Q.M. 2005. Determination of $\mathrm{Cd}$ and lead in different cigarette brands in Jordan. Environ. Monit. Assess. 104: 163-170. doi:10.1007/s10661-0051609-5. PMID: 15931985.

Michaud, S.E., Menard, C., Guy, L.G., Gennaro, G., and Rivard, A. 2003. Inhibition of hypoxia-induced angiogenesis by cigarette smoke exposure: impairment of the HIF-1alpha/VEGF pathway. FASEB J. 17: 1150-1152. PMID:12709416.

Mukhopadhyay, S., Shah, M., Patel, K., and Sehgal, P.B. 2006. Monocrotaline pyrrole-induced megalocytosis of lung and breast epithelial cells: disruption of plasma membrane and Golgi dynamics and an enhanced unfolded protein response. Toxicol. Appl. Pharmacol. 211: 209-220. doi:10.1016/j.taap.2005.06.004. PMID:16000202.

Nakashima, K., Yanagisawa, M., Arakawa, H., Kimura, N., Hisatsune, T., Kawabata, M., Miyazono, K., and Taga, T. 1999. Synergistic signaling in fetal brain by STAT3-Smad1 complex bridged by p300. Science, 284: 479-482. doi:10.1126/science. 284.5413.479. PMID:10205054.

Navas-Acien, A., Selvin, E., Sharrett, A.R., Calderon-Aranda, E., Silbergeld, E., and Guallar, E. 2004. Lead, Cd, smoking, and increased risk of peripheral arterial disease. Circulation, 109: 3196-3201. doi:10.1161/01.CIR.0000130848.18636.B2. PMID: 15184277.

Nelson, J.M., Duane, P.G., Rice, K.L., and Niewoehner, D.E. 1991. $\mathrm{Cd}$ ion-induced alterations of phospholipid metabolism in endothelial cells. Am. J. Respir. Cell Mol. Biol. 5: 328-336. PMID:1910817.

Nemery, B. 1990. Metal toxicity and the respiratory tract. Eur. Respir. J. 3: 202-219. PMID:2178966.

Nims, R.W., Cook, J.C., Krishna, M.C., Christodoulou, D., Poore, C.M., Miles, A.M., Grisham, M.B., and Wink, D.A. 1996. Colorimetric assays for nitric oxide and nitrogen oxide species formed from nitric oxide stock solutions and donor compounds. Methods Enzymol. 268: 93-105. PMID:8782576.

Oberdorster, G. 1986. Airborne Cd and carcinogenesis of the respiratory tract. Scand. J. Work Environ. Health, 12: 523-537. PMID:3547632.

Oldereid, N.B., Thomassen, Y., and Purvis, K. 1994. Seminal plasma lead, $\mathrm{Cd}$ and zinc in relation to tobacco consumption. Int. J. Androl. 17: 24-28. PMID:8005705.

Parast, C.V., Mroczkowski, B., Pinko, C., Misialek, S., Khambatta, G., and Appelt, K. 1998. Characterization and kinetic mechanism of catalytic domain of human vascular endothelial growth factor receptor-2 tyrosine kinase (VEGFR2 TK), a key enzyme in angiogenesis. Biochemistry, 37: 16788-16801. doi:10.1021/ bi981291f. PMID:9843450.

Peereboom-Stegeman, J.H., and Jongstra-Spaapen, E.J. 1979. The effect of a single sublethal administration of $\mathrm{Cd}$ chloride on the microcirculation in the uterus of the rat. Toxicology, 13: 199213. PMID:524376.

Puri, V.N. 1999. Cd induced hypertension. Clin. Exp. Hypertens. 21: 79-84. PMID:10052644.

Reeves, P.G., Chaney, R.L., Simmons, R.W., and Cherian, M.G. 2005. Metallothionein induction is not involved in Cd accumulation in the duodenum of mice and rats fed diets containing high$\mathrm{Cd}$ rice or sunflower kernels and a marginal supply of zinc, iron, and calcium. J. Nutr. 135: 99-108. PMID:15623840.

Sehgal, P.B., Guo, G.G., Shah, M., Kumar, V., and Patel, K. 2002. Cytokine signaling: STATS in plasma membrane rafts. J. Biol. Chem. 277: 12067-12074. doi:10.1074/jbc.M200018200. PMID: 11815625 .

Sessa, W.C. 2004. eNOS at a glance. J. Cell Sci. 117: 2427-2429. doi: $10.1242 /$ jes.01165.

Shah, M., Patel, K., Fried, V.A., and Sehgal, P.B. 2002. Interactions of STAT3 with caveolin-1 and heat shock protein 90 in plasma membrane raft and cytosolic complexes: preservation of cytokine signaling during fever. J. Biol. Chem. 277: 4566245669. doi:10.1074/jbc.M205935200. PMID:12235142.

Shah, M., Patel, K., and Sehgal, P.B. 2005. Monocrotaline pyrroleinduced endothelial cell megalocytosis involves a Golgi blockade mechanism. Am. J. Physiol. Cell Physiol. 288: C850-C862. doi:10.1152/ajpcell.00327.2004. PMID:15561761.

Skoczynska, A., and Martynowicz, H. 2005. The impact of subchronic Cd poisoning on the vascular effect of nitric oxide in rats. Hum. Exp. Toxicol. 24: 353-361. doi:10.1191/ 0960327105 ht536oa. PMID:16119249.

Staton, C.A., Stribbling, S.M., Tazzyman, S., Hughes, R., Brown, N.J., and Lewis, C.E. 2004. Current methods for assaying angiogenesis in vitro and in vivo. Int. J. Exp. Pathol. 85: 233-248. doi:10.1111/j.0959-9673.2004.00396.x. PMID:15379956.

Waalkes, M.P. 2003. Cd carcinogenesis. Mutat. Res. 533: 107-120. PMID:14643415.

Weidner, W.J., and Sillman, A.J. 1997. Low levels of Cd chloride damage the corneal endothelium. Arch. Toxicol. 71: 455-460. doi:10.1007/s002040050411. PMID:9209692.

Yu, J., DeMuinck, E.D., Zhuang, Z., Drinane, M., Kauser, K., Rubanyi, G.M., et al. 2005. Endothelial nitric oxide synthase is critical for ischemic remodeling, mural cell recruitment, and blood flow reserve. Proc. Natl. Acad. Sci. U.S.A. 102: 10999-11004. doi:10.1073/pnas.0501444102. PMID:16043715.

Yuan, T., Gomes, A.V., Barnes, J.A., Hunter, H.N., and Vogel, H.J. 2004. Spectroscopic characterization of the calmodulin-binding and autoinhibitory domains of calcium/calmodulin-dependent protein kinase I. Arch. Biochem. Biophys. 421: 192-206. doi:10.1016/j.abb.2003.11.012.

Zawadzka, T., Brulinska-Ostrowska, E., Wojciechowska-Mazurek, M., Cwiek, K., and Starska, K. 1989. Cd and lead levels in domestic and imported cigarettes. Rocz. Panstw. Zakl. Hig. 40: 145-152. PMID:2617056. 